\title{
Allele-Specific Expression of the MAOA Gene and $X$ Chromosome Inactivation in In Vitro Produced Bovine Embryos
}

\author{
A.R. FERREIRA,,$^{1,2}$ G.M. MACHADO, ${ }^{1,2}$ T.O. DIESEL, ${ }^{1,2}$ J.O. CARVALHO, ${ }^{1,3}$ R. RUMPF, ${ }^{1,2}$ E.O. MELO, ${ }^{1}$ \\ M.A.N. DODE, ${ }^{1,2}$ AND M.M. FRANCO ${ }^{1,2 *}$ \\ ${ }^{1}$ Embrapa Genetic Resources and Biotechnology, Laboratory of Animal Reproduction, Brasília, Brazil \\ ${ }^{2}$ School of Agriculture and Veterinary Medicine, University of Brasilia, Brasília, Brazil \\ ${ }^{3}$ Department of Animal Science, School of Agriculture Luiz de Queiroz, University of São Paulo, Piracicaba, Brazil
}

\begin{abstract}
SUMMARY
During embryogenesis, one of the two $X$ chromosomes is inactivated in embryos. The production of embryos in vitro may affect epigenetic mechanisms that could alter the expression of genes related to embryo development and $\mathrm{X}$ chromosome inactivation $(\mathrm{XCl})$. The aim of this study was to understand $\mathrm{XCl}$ during in vitro, pre-implantation bovine embryo development by characterizing the allele-specific expression pattern of the $X$ chromosome-linked gene, monoamine oxidase $A$ (MAOA). Two pools of ten embryos, comprised of the 4-, 8- to 16-cell, morula, blastocyst, and expanded blastocyst stages, were collected. Total RNA from embryos was isolated, and the RT-PCR-RFLP technique was used to observe expression of the MAOA gene. The DNA amplicons were also sequenced using the dideoxy sequencing method. MAOA mRNA was detected, and allele-specific expression was identified in each pool of embryos. We showed the presence of both the maternal and paternal alleles in the 4-, 8- to 16-cell, blastocyst and expanded blastocyst embryos, but only the maternal allele was present in the morula stage. Therefore, we can affirm that the paternal $X$ chromosome is totally inactivated at the morula stage and reactivated at the blastocyst stage. To our knowledge, this is the first report of allele-specific expression of an Xlinked gene that is subject to XCl in in vitro bovine embryos from the 4-cell to expanded blastocyst stages. We have established a pattern of $\mathrm{XCl}$ in our in vitro embryo production system that can be useful as a marker to assist the development of new protocols for in vitro embryo production. Mol. Reprod. Dev.
\end{abstract}

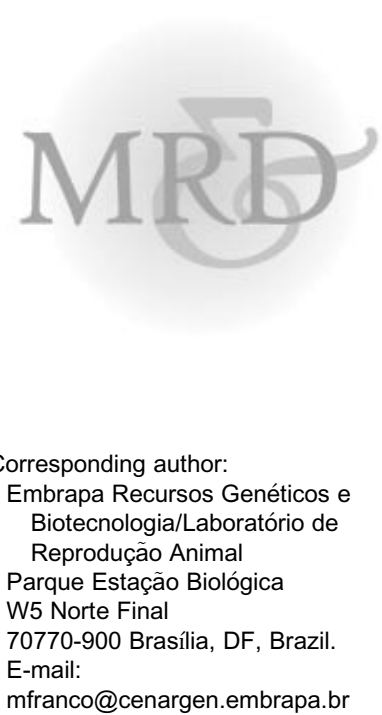

Mol. Reprod. Dev. 77: 615-621, 2010. (c) 2010 Wiley-Liss, Inc.

\section{INTRODUCTION}

In 1961, Mary F. Lyon proposed, for the first time, that there was a mechanism of dosage compensation to equalize gene expression of $X$-linked genes between sexes in mammals (Lyon, 1961). In eutherians, $X$ chromosome inactivation $(\mathrm{XCl})$ affects paternal or maternal $X$ chromosomes randomly during early development. The inactivated state is then stably inherited, and adult mosaics of two cell types, expressing either $\mathrm{X}$ chromosome, are produced (Heard and Disteche, 2006).

An imprint mark, protecting the maternal $X$ chromosome $(\mathrm{Xm})$ from $\mathrm{XCl}$, is acquired during oocyte maturation (Goto and Takagi, 1998, 2000; Tada et al., 2000), allowing the Xm to remain active during early embryogenesis. Conversely, after fertilization, there is a preferential inactivation of the paternal X chromosome (Xp) (Okamoto et al., 2004) that is 
maintained in the trophectoderm, but is reversed in the inner cell mass. Then, in the late blastocyst stage, the inactivated $X p$ is reactivated in those cells, where chromatin remodeling and final random $X$ inactivation take place, affecting either the $\mathrm{Xp}$ or the $\mathrm{Xm}$ in the embryonic derivatives.

Turner et al. (2004) commented that there is a considerable interest in understanding the mechanism by which the $X p$ is specifically kept silent in early development. During male meiosis, in which sperm are produced, a process known as meiotic sex chromosome inactivation (MSCl) occurs, and the sex chromosomes form a unique structure called the $\mathrm{XY}$ body. The process of $\mathrm{MSCl}$ occurs to prevent gene expression of $\mathrm{X}$ - (as well as $\mathrm{Y}$-) linked genes. This meiotic inactivation uniquely affects sex chromosomes and may be associated with the inability of the $X$ and $Y$ chromosomes to pair during male meiosis (Turner, 2007).

Huynh and Lee $(2003,2005)$ proposed that when an egg is fertilized, the $X p$ is in a pre-inactivated state. The authors suggested that this condition may be an extension of $\mathrm{MSCl}$, which persists during the pre-implantation period in the uterus; however, Okamoto et al. (2005) showed that genes on the Xp are transcriptionally active at the earliest embryonic stage and that subsequent inactivation of the Xp may occur independently of $\mathrm{MSCl}$. Therefore, these authors proposed that these processes represent two independent events, which suggests that there is a period after fertilization when the $X p$ is transcriptionally active.

The process of $X$ chromosome inactivation depends on the expression of a noncoding RNA called XIST (X inactivespecific transcript). Synthesis of XIST RNA increases, and RNA molecules accumulate on the chromosome that is targeted to be inactivated. Coating the $\mathrm{X}$ chromosome with XIST RNAs leads to the acquisition of repressive epigenetic marks including DNA methylation and core histone modifications, which consequently silence genes on the chromosome (Brockdorff, 2002). Gene methylation and gene activity are often inversely correlated (Yeivin and Razin, 1993). The significance of methylation for transcriptional silencing is further demonstrated by in vitro methylation of promoter sequences or artificial demethylation of gene sequences, resulting in repression and activation of gene activity, respectively (Bird, 2002).

The influence of assisted reproductive technologies on epigenetic patterns has been well documented (Young et al., 2001; De Rycke et al., 2002; Thompson et al., 2002; Gosden et al., 2003). In fact, the observation that in vitro culture could affect epigenetic processes in ruminants was first documented by Young et al. (2001). The authors found that sheep with a condition resulting in overgrowth abnormalities, known as "large offspring syndrome," showed altered expression and aberrant methylation patterns in the insulin-like growth factor 2 receptor (IGF2R) gene.

DNA methylation is an essential epigenetic process in embryo development, and it is important for normal gene regulation, $\mathrm{XCl}$, and genomic imprinting (Reik et al., 2001). In vitro embryo production systems may affect DNA methylation patterns that could interfere in the expression of genes related to embryo development (Shi and Haaf, 2002; Lucifero et al., 2004; Ludwig et al., 2004; Chang et al., 2005). Considering that $\mathrm{XCl}$ is dependent on DNA methylation, it is possible that assisted reproductive technologies (ARTS) affect this process, which could compromise embryo quality and pregnancy rates. Yet, a lack of information for species other than humans and mice, especially in bovines, has limited our knowledge about the extent to which XCI may be affected by artificial reproductive conditions. Therefore, the establishment of the pattern and timing of $\mathrm{XCl}$ in bovine embryos is a prerequisite for subsequent studies on this process and other epigenetically controlled phenomena.

The monoamine oxidase A (MAOA) gene, located on the $X$ chromosome, encodes a major factor involved in the regulation of serotonin levels during pregnancy (Liu et al., 2008). According to Yu et al. (2005), it is a mitochondrial enzyme involved in the degradation of biogenic amines. It is implicated in the pathogenesis of major depressive disorder (MDD) and is related to the therapeutic effects of antidepressants. The MAOA gene is a paternally imprinted gene only in the extra-embryonic tissues and shows bi-allelic expression in adult tissues (Liu et al., 2008). Moreover, Xue et al. (2002) have demonstrated random and mono-allelic expression of MAOA, indicating that this gene is subject to $\mathrm{XCl}$ in cattle. Because a single nucleotide polymorphism in that gene has also been identified, it is a good candidate to be used for studies related to $\mathrm{XCl}$ in bovines.

Therefore, in the present study, we investigated the $X$ chromosome inactivation pattern during development of in vitro pre-implantation bovine embryos, by characterizing the allele-specific expression pattern of the $\mathrm{X}$ chromosomelinked MAOA gene.

\section{RESULTS}

A total of 1,013 cumulus-oocyte complexes (COC) were used in a seven replicate experiment. An average of 16.07 $\mathrm{COC}$ per heifer was recovered per aspiration section. In a pre-experiment, performed to evaluated X-sorted semen from the selected bull, we found a day 7 (D7) blastocyst rate of $29.3 \%$. The embryos were then sexed by polymerase chain reaction (PCR), and the results showed that $16.3 \%$ were male $(n=49)$. The blastocyst rate was not able to be determined because the embryos were collected in different stages of development; however, an in vitro fertilization (IVF) control was carried out using our reference bull simultaneously in all replicates, which showed a mean cleavage rate of $81 \%$ and a blastocyst rate (D7) of $40 \%$.

To perform the MAOA phenotyping and gene expression evaluation, CDNA was used from two pools of 10 embryos for each stage of development [4-cell (44 hr pi), 8- to 16-cell ( $72 \mathrm{hr}$ pi), morula (144 hr pi), blastocyst (156 hr pi), and expanded blastocyst (168 hr pi)]. The expression of the MAOA gene was detected in all pools of embryos and at all stages of development. Bi-allelic expression (Xm and Xp) was detected in all stages, except in the morula stage, where only the maternal $X$ was active (Fig. 1).

DNA sequencing confirmed phenotyping data, showing mono-allelic expression in morula (Fig. 2), with only Xm expressed (the A allele).

In addition to detecting MAOA mRNA in all stages of embryo development, MAOA mRNA was also expressed in 

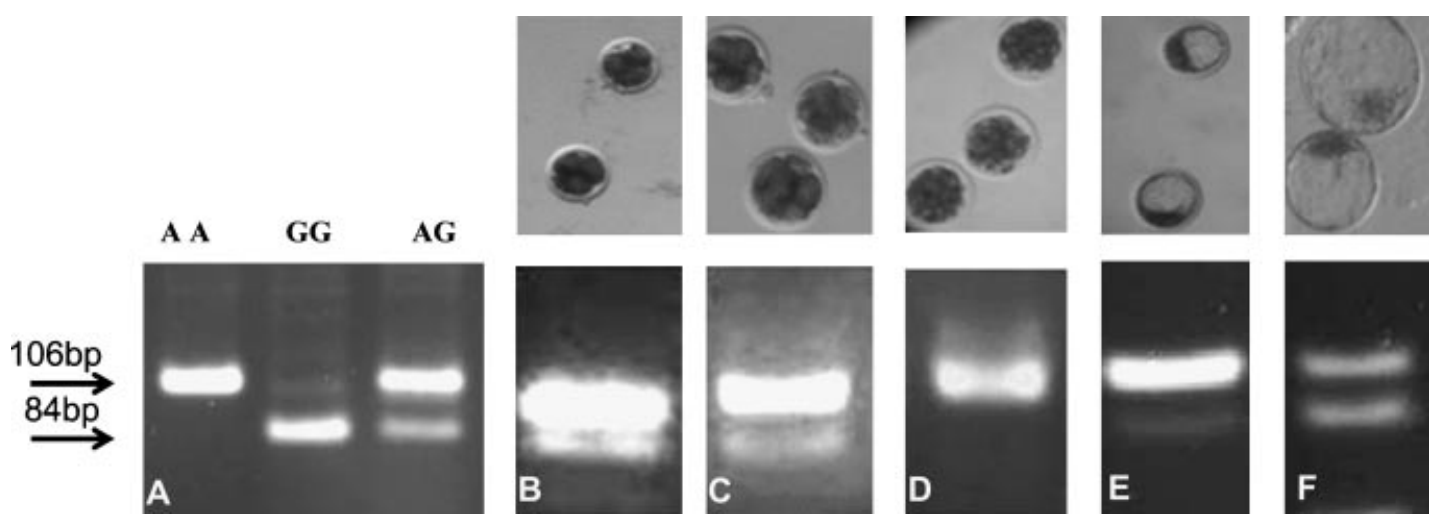

Figure 1. Phenotyping of the MAOA gene by RT-PCR-RFLP. The PCR products were run on $3 \%$ agarose gels. A: PCR-RFLP using genomic DNA as a control, showing the AA (106 bp), GG (84 bp) and AG (106 and $84 \mathrm{bp})$ MAOA genotypes. B: RT-PCR-RFLP for the four-cell stage (A and G alleles); (C) 8-16 cell stage (A and $G$ alleles); (D) morula stage ( $A$ allele); (E) blastocyst stage ( $A$ and $G$ alleles); (F) expanded blastocyst stage (A and $\mathrm{G}$ alleles). The $22 \mathrm{bp}$ fragment is not visible in the gel. bp, base pairs.

the X-sorted semen used in IVF and in mature oocytes (Fig. 3).

\section{DISCUSSION}

Bi-allelic expression ( $\mathrm{Xm}$ and $\mathrm{Xp}$ ) of the MAOA gene was detected in the 4-cell, 8- to 16-cell, blastocyst and expanded blastocyst stages of embryo development. The maternal copy of the MAOA gene was expressed in the morula stage while the paternal copy was inactivated. This result, shown in Figure 1, was confirmed by DNA sequencing (Fig. 2). In this discussion, the term "bi-allelic expression" will refer to the presence of both paternal and maternal alleles in a pool of embryos, rather than in a single cell.

In eutherians, $X$-chromosome inactivation $(X \mathrm{Cl})$ affects paternal or maternal $X$ chromosomes randomly during early development, and the inactive state is then stably inherited,

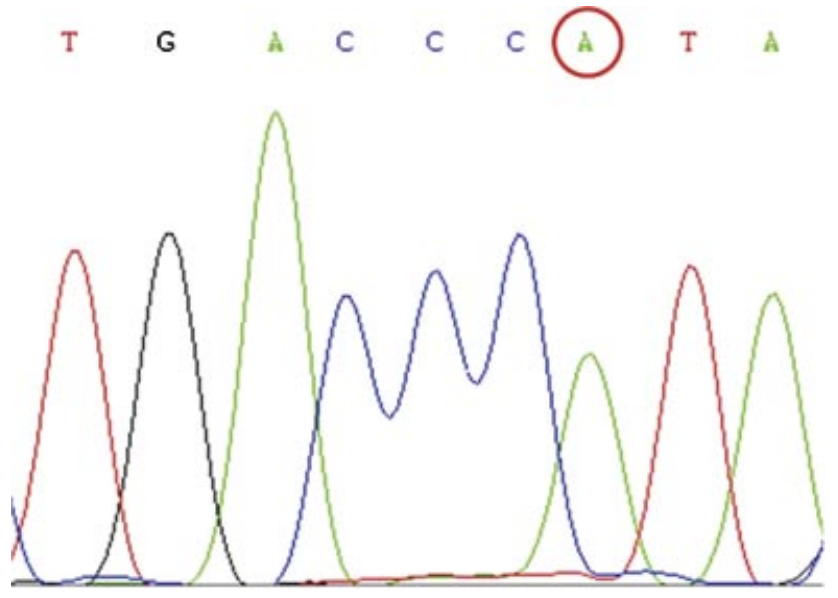

Figure 2. DNA chromatogram showing part of a sequence of the MAOA gene in samples from the morula stage. The open circle in the sequence shows the exclusive presence of the A allele. resulting in adult mosaics of two cell types, expressing either X chromosome (Heard and Disteche, 2006). Expression of a gene from only one parental contributor of a chromosome pair is known as imprinting, which is caused by an epigenetic memory acquired during gametogenesis (Lucchesi et al., 2005).

Maternal imprinting, in which the $\mathrm{Xm}$ is protected from $\mathrm{XCl}$, is acquired during oocyte maturation (Goto and Takagi, 1998, 2000; Tada et al., 2000). Therefore, it is expected that the $\mathrm{Xm}$ is active after fertilization. This mechanism probably evolved to ensure gene activity in a single copy of the $X$ chromosome in males. Huynh and Lee $(2003,2005)$ proposed that the male $\mathrm{X}$ chromosome is in a pre-inactivated state at the moment of fertilization. They suggest that this state may be an extension of $\mathrm{MSCl}$, which persists during pre-implantation stage of embryos in the uterus. On the other hand, Okamoto et al. (2004) found that the paternally inherited $\mathrm{X}$ chromosome is initially active after fertilization and becomes inactivated following accumulation of XIST RNA. It is important to point out that all of the studies

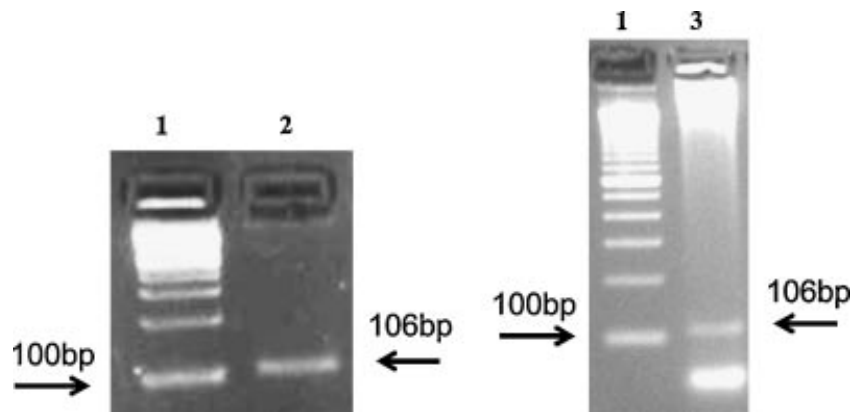

Figure 3. RT-PCR to detect expression of the MAOA gene in X-sorted semen and mature oocytes. The PCR products were run on $3 \%$ agarose gels. Lane 1-100 bp molecular weight marker. Lane 2: MAOA amplicon (106 bp) detected in X-sorted semen. Lane 3: MAOA amplicon (106 bp) detected in mature oocytes. bp, base pairs. 
mentioned above were carried out using mouse pre-implantation embryos.

Considering that $16.3 \%$ of the embryos produced with the sexed sperm used in this study were male, we cannot eliminate the possibility that a male embryo was present in the pools. There is a consensus that the $\mathrm{Xm}$ remains active, independent of the sex of the embryo, until the blastocyst stage (Goto and Takagi, 1998, 2000; Tada et al., 2000). Therefore, the maternal MAOA mRNA that was detected in all embryo stages in this experiment may have come from either male or female embryos. Yet, what allowed the establishment of allele-specific expression patterns of the MAOA gene was the presence of the paternal allele, which obviously comes from the female embryos. As a result, the possible presence of male embryos did not interfere with the conclusions made by our results.

Huynh and Lee $(2003,2005)$, proposed that one X chromosome is already silent at the two-cell stage when zygotic gene activation occurs in mice, suggesting that the $X$ chromosomes are already dosage compensated from conception. On the contrary, our results showed the presence of mRNA from both alleles of the MAOA gene in the 4-cell stage, before major embryonic gene activation which occurs at the 8- to 16-cell stage in bovine embryos. Therefore, the presence of MAOA mRNAs from both parental alleles in the 8- to 16-cell stage of embryogenesis may suggest that dosage compensation does not happen until this stage in bovines.

Okamoto et al. (2004) suggested that, in mice, the Xp starts out active and is gradually inactivated during the initial stages of development. In the present study, we observed a similar pattern of Xp inactivation in bovines because we detect both parental alleles of MAOA in 4- and 8- to 16-cell embryos with mono-allelic maternal expression in morulae (Fig. 1). On the other hand, although we have detected MAOA mRNA in 4- and 8- to 16-cell embryos, we cannot ensure that there was gene expression activity in the $X$ chromosomes. It is possible that the mRNA has come from semen and/or oocytes (Fig. 3); however, this possibility seems unlikely considering that the paternal allele detected until 8- to 16-cell embryo development comes from only 10 sperm cells per pool of embryos. Thus, we can speculate that the $\mathrm{Xp}$ is active in 4-cell embryos, suggesting that the embryonic genome becomes active at this time in cattle, which is in agreement with Park et al. (1999). If we take into account that one pool of 10 embryos contains paternal mRNA from only 10 spermatozoa, as well as the possibility that the MAOA gene is transcribed at a low rate on the paternal chromosome, we can conclude that few paternal molecules are present in the embryos at the earliest stages. As a result, it was necessary to perform two rounds of amplification to detect paternal MAOA mRNA in the embryos. After the morula stage, we can affirm that both $X$ chromosomes are active because mRNA from both alleles was detected. This is in contrast to morula stage embryos, in which only MAOA mRNA from the Xm was observed (Fig. 1). Conversely, it is important to point out that our experiment was done using embryos produced in vitro, which can influence gene expression (Niemann and Wrenzycki, 2000; Rizos et al., 2002) and the $\mathrm{XCl}$ process.
Okamoto et al. (2004) found that, in mice, the Xp was inactive in the embryonic cells isolated from the inner cell mass until the blastocyst stage; however, by the late blastocyst stage, the $\mathrm{Xp}$ is reactivated in the inner cell mass, allowing chromatin remodeling and subsequent random $X$ chromosome inactivation in the embryonic derivatives. Similar results, using an in vivo model, were obtained by Mak et al. (2004). In contrast, we had already detected the presence of both alleles at the blastocyst stage. The reason for the difference between our results and those of Okamoto et al. (2004) and Mak et al. (2004) is related to the embryo stage at which the $X p$ is reactivated, which is probably due to significant differences in the dynamics of development between mouse and bovine embryos.

Until the morula stage, the embryo is composed of a single cell type, with the first differentiation event happening in the blastocyst. According to Huynh and Lee (2003), in the morula, some cells lose their imprint mark related to $\mathrm{XCl}$, which contributes to inner cell mass formation. In the blastocyst, $\mathrm{Xp}$ is preferentially inactivated in trophoblast cells, and $\mathrm{XCl}$ occurs randomly in the inner cell mass (Heard and Disteche, 2006). In this study, we used whole embryos; consequently, we were not able to confirm bi-allelic expression in the inner cell mass and maternal expression in the trophoblast; however, this was not the objective of our study.

Regarding the molecular mechanisms related to $\mathrm{XCl}$, the first event that happens seems to be the accumulation of XIST RNA on the X chromosome that will be inactivated (De La Fuente et al., 1999). Following this, a complex of Eed proteins starts to accumulate on this chromosome. Plath et al. $(2002,2003)$ comment that Eed protein accumulation is an important event in maintaining an $\mathrm{X}$ chromosome in an inactive state. On the other hand, Rougeulle et al. (2004) state that the accumulation of the Eed/Ezh2 complex, which is related to gene silencing and enzyme activity, is a marker that signals the beginning of $\mathrm{XCl}$. The presence of the Eed protein on the inactive $X$ chromosome in $X X$ embryos has been detected starting from the morula stage (Silva et al., 2003). Therefore, our results are in agreement with this finding because we showed mono-allelic expression of the MAOA gene in morulae, which confirms that the $X p$ is inactive at that stage.

We were able to determine allele-specific expression of the MAOA gene, which can be used to speculate about the pattern of $\mathrm{X}$ chromosome inactivation in bovine embryos; however, we have to be cautious in comparing our results to the literature because the majority of studies published have used mouse embryos, and the dynamics of embryo development are completely different between the two species. One question that remains to be answered regards the origin of both MAOA alleles detected in early embryos, before embryo gene activation. The MAOA mRNAs may be from sperm and oocytes, or, perhaps, from the active Xm and Xp in those early stages. Another important consideration is that our study was carried out with in vitro embryos, thus our culturing system may have influenced the timing of $X$ inactivation. Therefore, to characterize $\mathrm{X}$ chromosome inactivation in in vivo bovine embryos, it is important to know if there is any influence of the in vitro system on this important epigenetic event. 
To our knowledge, our data is the first characterization of allele-specific expression of an X-linked gene that is subject to $\mathrm{XCl}$ in in vitro bovine embryos from the four-cell to the expanded blastocyst stages. We believe our system can be useful as a marker to assist the development of new protocols for in vitro embryo production.

\section{MATERIALS AND METHODS}

\section{Animals}

To identify the allele-specific expression of the MAOA gene, we used the same approach described by Xue et al. (2002), which is based on the amplification of a region of DNA flanking a single nucleotide polymorphism. First, we searched for the polymorphism among Nellore and Holstein breeds. Then, we selected a Holstein bull that was homozygous for the $G$ allele using commercially available, X-sorted semen (ABS Pecplan, São Paulo, Brazil) that had been previously tested for IVF. For oocyte donors, we selected nine Nellore females that were homozygous for the A allele. Animals were handled according to Brazilian legislation, and the experiment was approved by the ethics committee of the University of Brasilia, Brazil (UnBDOC no. 79396/2008).

\section{In Vitro Embryo Production}

Chemicals used for in vitro embryo production were purchased from Sigma Chemical Co (St. Louis, MO) unless otherwise indicated.

Cumulus oocyte complexes (COCs) from nine Nellore heifers (Bos taurus indicus) were aspirated from follicles ranging in size from 2 to $8 \mathrm{~mm}$ diameter. The heifers were submitted each week to seven sections of follicular aspiration guided by ultrasound (OPU). The equipment used consisted of an ultrasound device (Aloka SSD $500^{\circledR}$, Tokyo, Japan) coupled with a micro-convex transducer/ probe $(7.5 \mathrm{MHz}$, UST 9125 model-7.5; Aloka) and a trans-vaginal guide (WTA, Cravinhos, São Paulo, Brazil), and a vacuum pump VMAR5100 (Cook, Brisbane, Australia) combined with a system with an $18 \mathrm{G}$ needle $(0.9 \mathrm{~mm} \times 70 \mathrm{~mm})(\mathrm{WTA})$. Only COC with homogenous cytoplasm and at least three layers of cumulus cells were used. A total of 30-35 COC were placed in a $200 \mu$ l drop of maturation medium, to which silicone oil was added, and incubated for $22 \mathrm{~h}$ at $39^{\circ} \mathrm{C}$ in $5 \% \mathrm{CO}_{2}$. The maturation medium consisted of TCM-199 Earle's salts (Invitrogen, Carlsbad, CA) supplemented with $10 \%$ fetal calf serum (FCS) (Invitrogen), $12 \mathrm{IU} / \mathrm{ml}$ of $\mathrm{LH}$, $0.01 \mathrm{IU} / \mathrm{ml}$ of $\mathrm{FSH}$ and antibiotic (Amicacyn, $0.075 \mathrm{mg} / \mathrm{ml}$ ).

After maturation, the COC were transferred to a $200 \mu \mathrm{l}$ drop of TALP fertilization medium (Parrish et al., 1995) supplemented with penicillamine $(2 \mathrm{mM})$, hypotaurine $(1 \mathrm{mM})$, epinephrine $(250 \mathrm{mM})$ and heparin $(10 \mu \mathrm{g} / \mathrm{ml})$ and inseminated with X-sorted semen from the selected bull. Frozen semen from a bull that is routinely used in our laboratory and had successfully been used in previous in vitro fertilizations was used as a control. For sperm selection, thawed semen was layered on top of a gradient composed of $0.4 \mathrm{~m}$ fractions of $45 \%$ and $60 \%$ Percoll and centrifuged for $5 \mathrm{~min}$ at
$700 \times g$. After centrifugation, the supernatant was discarded and the pellet was re-suspended and centrifuged for $2 \mathrm{~min}$ in fertilization medium at $300 \times g$. The resulting pellet was re-suspended in fertilization medium and added to a fertilization drop at a final concentration of $1 \times 10^{6}$ spermatozoa $\mathrm{ml}^{-1}$. Spermatozoa and oocytes were co-incubated for $18 \mathrm{~h}$ at $39^{\circ} \mathrm{C}$ with $5 \% \mathrm{CO}_{2}$, with the day of in vitro insemination considered as Day 0.

After co-incubation, the presumptive zygotes were washed and transferred to $200 \mu \mathrm{l}$ drops of SOFaaci medium (Holm et al., 1999) supplemented with $2.77 \mathrm{mM}$ of myo-inositol and 5\% FCS and cultured at $39^{\circ} \mathrm{C}$ with $5 \% \mathrm{CO}_{2}$ for 7 days. Embryos produced with semen from the control bull were evaluated on D2 post-insemination (pi) for cleavage and on D6 and D7 pi for blastocyst rates.

Twenty embryos were produced in each developmental stage [4-cell ( $44 \mathrm{hr}$ pi), 8- to 16-cell (72 hr pi), morula (144 hr pi), blastocyst (156 hr pi), and expanded blastocyst (168 hr pi)] that were heterozygous for the A/G MAOA polymorphism. Two pools of ten embryos from each stage were frozen in RNAlater $\left(\right.$ Ambiom $\left.^{\circledR}\right)$ and stored at $-80^{\circ} \mathrm{C}$ until RNA isolation.

\section{RNA and DNA Isolation and Reverse Transcription}

Total RNA from the pools of embryos and from a pool of 15 mature oocytes was isolated using the Invisorb Spin Cell kit (Invitek) according to the manufacturer's protocol. Total RNA from X-sorted semen was isolated from 5 straws using TRIzol Reagent (Invitrogen) following the manufacturer's protocol with some modifications. In brief, thawed semen was layered over a Percoll gradient of $40-70 \%$ and centrifuged at $700 \mathrm{~g}$ for $45 \mathrm{~min}$ to eliminate the possibility of contamination with somatic cells. Then, TRIzol was added, and the sample was incubated at $60^{\circ} \mathrm{C}$ for $30 \mathrm{~min}$. After RNA isolation, the samples were incubated with $1 \mathrm{U}$ DNAse I (Invitrogen) and reverse transcribed with $200 \mathrm{U}$ of SuperScript III (200 U/ $\mu \mathrm{l}$; Invitrogen) using $0.5 \mu \mathrm{g}$ of oligo-dT ${ }_{12-18} \operatorname{primer}(0.5 \mu \mathrm{g} / \mu \mathrm{l}$; Invitrogen). Reactions were performed at $65^{\circ} \mathrm{C}$ for $5 \mathrm{~min}$ and $42^{\circ} \mathrm{C}$ for $52 \mathrm{~min}$, followed by enzyme inactivation at $70^{\circ} \mathrm{C}$ for $15 \mathrm{~min}$.

Genomic DNA was isolated from semen and leukocytes using a protocol based on salting out (Biase et al., 2002).

\section{MAOA Genotyping}

Animals that were selected for use in subsequent experiments were genotyped for the A/G polymorphism within the MAOA gene. Two pairs of primers were designed based on GenBank sequence number NM_181014.2 (Table 1) to be used in genotyping and gene expression experiments. Using the inner reverse primer, a mutation was introduced near the $A / G$ polymorphism to create an Rsal restriction site. For genotyping, only internal primers were used. PCR was performed using $50 \mathrm{ng}$ of genomic DNA, 1X PCR buffer, $1.0 \mathrm{mM} \mathrm{MgCl}, 200 \mu \mathrm{M}$ of each dNTP, $0.5 \mu \mathrm{M}$ of each internal primer and $1.0 \mathrm{U}$ of Platinum Taq DNA polymerase (Invitrogen) in a final volume of $20 \mu \mathrm{l}$. Reactions were run in a PTC-100 thermocycler (MJ Research, Waltham, MA) using the following conditions: $94^{\circ} \mathrm{C}$ for $3 \mathrm{~min}, 36$ cycles of $94^{\circ} \mathrm{C}$ for $30 \mathrm{sec}, 54^{\circ} \mathrm{C}$ for $30 \mathrm{sec}$ and $72^{\circ} \mathrm{C}$ for $40 \mathrm{sec}$ and a final extension step at $72^{\circ} \mathrm{C}$ for $10 \mathrm{~min}$. This amplification resulted in a PCR product of $106 \mathrm{bp}$ in size. After

TABLE 1. Primers Sequences, Amplicon Size, and Annealing Temperature (AT)

\begin{tabular}{llcc}
\hline Gene & \multicolumn{1}{c}{ Primers set $\left(5^{\prime}-3^{\prime}\right)$} & Amplicon size $(\mathrm{bp})$ & AT $\left({ }^{\circ} \mathrm{C}\right)$ \\
\hline \multirow{3}{*}{ bMAOA } & Out forward: AGG CCT GCT GAA GAT TGT TG & 178 \\
& Out reverse: GAT GAT CTG ATT GCA CGG CT & 106 & 51 \\
& Inner forward: GCT GCT AAG CCG ATC CTG AAG T & $52 / 54^{\mathrm{a}}$ \\
& Inner reverse: GAT CTG ATT GCA CGG CTG TTG TA & & \\
\hline
\end{tabular}

aGenotyping using genomic DNA. 
amplification, $13 \mu \mathrm{l}$ of amplicon were digested overnight at $37^{\circ} \mathrm{C}$ with $10 \mathrm{U}$ of $R$ sal restriction enzyme (Promega, Madison, $\mathrm{WI})$. DNA fragments were electrophoretically separated in $3 \%$ agarose gels, stained with ethidium bromide $(10 \mathrm{mg} / \mathrm{ml})$ and photographed under UV light. The A allele produced a $106 \mathrm{bp}$ fragment, whereas the $G$ allele yielded two fragments of 84 and $22 \mathrm{bp}$. Negative controls, in which DNA template was omitted from the reaction, were included in all PCR assays. Positive controls for all Rsal digestions were included, using three DNA samples with known MAOA genotypes.

\section{RT-PCR-RFLP for MAOA Expression}

To identify allele-specific expression of the MAOA gene in the embryos, a nested PCR was employed with both pairs of primers described in Table 1. We were able to phenotype this gene in the embryos because the $G$ allele comes from the bull and the $A$ allele from the oocyte donors. After reverse transcription and two rounds of amplification, PCR products were digested with the Rsal restriction enzyme, which allowed the identification of the parental origin of the expressed allele. Primers were designed flanking a single nucleotide polymorphism and the sequence of the inner reverse primer to create a restriction site for the Rsal enzyme and allow for the detection of allele-specific expression of MAOA from Bos taurus taurus or Bos taurus indicus chromosomes. To detect MAOA expression in semen and oocytes, we used only one round of amplification with the outer primers. The first round of amplification was performed using $1.0 \mu \mathrm{l}$ of cDNA from each pool of embryos, semen or oocytes, along with $1 \times$ PCR buffer, $1.0 \mathrm{mM} \mathrm{MgCl}_{2}, 200$ $\mu \mathrm{M}$ of each dNTP, $0.5 \mu \mathrm{M}$ of each outer primer and $1.0 \mathrm{U}$ Platinum Taq DNA polymerase (Invitrogen) in a final volume of $20 \mu \mathrm{l}$. The reactions were run in a PTC- 100 thermocycler (MJ Research) using the following conditions: $94^{\circ} \mathrm{C}$ for $3 \mathrm{~min}, 40$ cycles of $94^{\circ} \mathrm{C}$ for $30 \mathrm{sec}, 51^{\circ} \mathrm{C}$ for $30 \mathrm{sec}$ and $72^{\circ} \mathrm{C}$ for $40 \mathrm{sec}$ and a final extension step at $72^{\circ} \mathrm{C}$ for $10 \mathrm{~min}$. This amplification resulted in a PCR product of $178 \mathrm{bp}$. The second round of amplification was performed using $1.0 \mu \mathrm{l}$ of the first PCR from the embryos as template, $1 \times$ PCR buffer, $1.5 \mathrm{mM} \mathrm{MgCl}, 200 \mu \mathrm{M}$ of each dNTP, $0.5 \mu \mathrm{M}$ of each internal primer and 1.0 U Platinum Taq DNA polymerase (Invitrogen) in a final volume of $20 \mu \mathrm{l}$. The reactions were run in a PTC-100 thermocycler (MJ Research) using the following conditions: $94^{\circ} \mathrm{C}$ for $3 \mathrm{~min}$, 40 cycles at $94^{\circ} \mathrm{C}$ for $30 \mathrm{sec}, 52^{\circ} \mathrm{C}$ for $30 \mathrm{sec}$, and $72^{\circ} \mathrm{C}$ for $40 \mathrm{sec}$, followed by a final extension at $72^{\circ} \mathrm{C}$ for $10 \mathrm{~min}$. Nested PCR produced an amplicon of $106 \mathrm{bp}$. Three first-round PCR replicates and two second-round PCR replicates from each pool of embryos were done. After both rounds of PCR were performed, $13 \mu \mathrm{l}$ of the PCR amplicon were digested overnight at $37^{\circ} \mathrm{C}$ using $10 \mathrm{U}$ of $R$ sal restriction enzyme (Promega). The alleles were detected in $3 \%$ agarose gels, stained with ethidium bromide $(10 \mathrm{mg} / \mathrm{ml})$ and photographed under UV light. The A allele produced a $106 \mathrm{bp}$ fragment, whereas the $G$ allele yielded two fragments of 84 and $22 \mathrm{bp}$. As negative controls, $\mathrm{PCR}$ reactions were performed in the absence of cDNA template.

DNA Sequencing RT-PCR amplicons generated from each pool of embryos were produced and purified using ammonium acetate $(7.5 \mathrm{M})$ and absolute ethanol. Following this, purified amplicons were sequenced using the dideoxy fluorescence terminator system $(A B I 3130 \times I)$ with the inner forward primer.

\section{Data Analysis}

A descriptive analysis was done for MAOA phenotyping data. We analyzed the presence of the amplified fragment and parental origin of alleles by analyzing the amplicon size in agarose gels and by comparing DNA sequence homology using Chromas and DNAMAN softwares.

\section{ACKNOWLEDGMENTS}

This research was funded by Embrapa and CNPq, Brazil. ARF wishes to thank CAPES for financial support.

\section{REFERENCES}

Biase FH, Franco MM, Goulart LR, Antunes RC. 2002. Protocol for extraction of genomic DNA from swine solid tissues. Genet Mol Biol 25:313-315.

Bird A. 2002. DNA methylation patterns and epigenetic memory. Genes Dev 16:6-21.

Brockdorff N. 2002. X-chromosome inactivation: Closing in on proteins that bind XIST RNA. Trends Genet 18:352-358.

Chang AS, Moley KH, Feinberg AP, Wangler M, Debaun MR. 2005. The association between Beckwith-Weidemann syndrome and assisted reproductive technology: A case series of nineteen patients. Fertil Steril 83:349-354.

De La Fuente R, Hahnel A, Basrur PK, King WA. 1999. X inactivespecific transcript (XIST) expression and $X$ chromosome inactivation in the preattachment bovine embryo. Biol Reprod 60: 769-775.

De Rycke M, Liebaers I, Van Steirteghem A. 2002. Epigenetic risks related to assisted reproductive technologies: Risk analysis and epigenetic inheritance. Hum Reprod 17:2487-2494.

Gosden R, Trasler J, Lucifero D, Faddy M. 2003. Rare congenital disorders, imprinted genes, and assisted reproductive technology. Lancet 361:1975-1977.

Goto Y, Takagi N. 1998. Tetraploid embryos rescue embryonic lethality caused by an additional maternally inherited $X$ chromosome in the mouse. Development 125:3353-3363.

Goto Y, Takagi N. 2000. Maternally inherited X chromosome is not inactivated in mouse blastocysts due to parental imprinting. Chromosome Res 8:101.

Heard E, Disteche CM. 2006. Dosage compensation in mammals: Fine tuning the expression of the $X$ chromosome. Genes Dev 20:1848-1867.

Holm P, Booth PJ, Schmidt MH, Greve T, Callesen H. 1999. High bovine blastocyst development in a static in vitro production system using SOFaa medium supplemented with sodium citrate and myo-inositol with or withoutserum-proteins. Theriogenology 52:683-700.

Huynh KD, Lee JT. 2003. Inheritance of a pre-inactivated paternal X chromosome in early mouse embryos. Nature 426:857-862.

Huynh KD, Lee JT. 2005. X-chromosome inactivation: A hypothesis linking ontogeny and phylogeny. Nature 10:8-16.

Liu JH, Yin S, Xiong B, Hou Y, Chen DY, Sun QY. 2008. Aberrant DNA methylation imprints in aborted bovine clones. Mol Reprod Dev 75:598-607.

Lucchesi JC, Kelly WG, Panning B. 2005. Chromatin remodeling in dosage compensation. Annu Rev Genet 39:615-651.

Lucifero D, Mann MRW, Bartolomei MS, Trasler JM. 2004. Genespecific timing and epigenetic memory in oocyte imprinting. Hum Mol Genet 13:839-849.

Ludwig M, Katalinic A, Gross S, Varon R, Horsthemke B. 2004. Increased prevalence of imprinting defects in Angelman Syndrome (AS) patients born to infertile couples. Fertil Steril 82:49.

Lyon MF. 1961. Gene action in the X-chromosome of the mouse (Mus musculus L.). Nature 190:372-373. 
Mak W, Nesterova TB, De Napoles M, Appanah R, Yamanaka S, Otte AP, Brockdorff N. 2004. Reactivation of the paternal $X$ chromosome in early mouse embryos. Science 303:666-669.

Niemann H, Wrenzycki C. 2000. Alterations of expression of developmentally important genes in preimplantation bovine embryos by in vitro culture conditions: Implications for subsequent development. Theriogenology 53:21-34.

Okamoto I, Otte AP, Allis CD, Reinberg D, Heard E. 2004. Epigenetic dynamics of imprinted $\mathrm{X}$ inactivation during early mouse development. Science 303:644-649.

Okamoto I, Arnaud D, Le Baccon P, Otte AP, Disteche CM, Avner P, Heard E. 2005. Evidence for de novo imprinted X-chromosome inactivation independent of meiotic inactivation in mice. Nature 438:369-373.

Park E-H, Chian R-C, Chung H-M, Lim J-G, Ko J-J, Cha K-Y. 1999. The stage of embryonic genome activation in bovine embryos following in vitro fertilization. Theriogenology 51:188.

Parrish JJ, Krogenaes A, Susko-Parrish JL. 1995. Effect of bovine sperm separation by either swim-up or Percoll method on success of in vitro fertilization and early embryonic development. Theriogenology 44:859-869.

Plath K, Mlynarczyk-Evans S, Nusinow DA, Panning B. 2002. XIST RNA and the mechanism of $X$ chromosome inactivation. Annu Rev Genet 36:233-278.

Plath K, Fang J, Mlynarczyk-Evans SK, Cao R, Worringer KA, Wang H, De La Cruz CC, Otte AP, Panning B, Zhang Y. 2003. Role of histone $\mathrm{H} 3$ lysine 27 methylation in $\mathrm{X}$ inactivation. Science 300:131-135.

Reik W, Dean W, Walter J. 2001. Epigenetic reprogramming in mammalian development. Science 293:1089-1093.

Rizos D, Lonergan P, Boland MP, Arroyo-García R, Pintado B, De La Fuente J, Gutiérrez-Adán A. 2002. Analysis of differential messenger RNA expression between bovine blastocysts produced in different culture systems: Implications for blastocyst quality. Biol Reprod 66:589-595.

Rougeulle C, Chaumeil J, Sarma K, Allis CD, Reinberg D, Avner P, Heard E. 2004. Differential histone H3 Lys-9 and Lys-27 methylation profiles on the X chromosome. Mol Cell Biol 24:5475-5484.
Shi W, Haaf T. 2002. Aberrant methylation patterns at the two-cell stage as an indicator of early developmental failure. Mol Reprod Dev 63:329-334.

Silva J, Mak W, Zvetkova I, Appanah R, Nesterova TB, Webster Z, Peters AH, Jenuwein T, Otte AP, Brockdorff N. 2003. Establishment of histone $h 3$ methylation on the inactive $X$ chromosome requires transient recruitment of Eed-Enx1 polycomb group complexes. Dev Cell 4:481-495.

Tada T, Obata Y, Tada M, Goto Y, Nakatsuji N, Tan S, Kono T, Takagi N. 2000. Imprint switching for non-random X-chromosome inactivation during mouse oocyte growth. Development 127:3101-3105.

Thompson JG, Kind KL, Roberts CT, Robertson SA, Robinson JS. 2002. Epigenetic risks related to assisted reproductive technologies: Short- and long-term consequences for the health of children conceived through assisted reproduction technology: More reason for caution? Hum Reprod 17:27832786.

Turner JMA. 2007. Meiotic sex chromosome inactivation. Development 134:1823-1831.

Turner JM, Aprelikova O, Xu X, Wang R, Kim S, Chandramouli GV, Barrett JC, Burgoyne PS, Deng CX. 2004. BRCA1, histone H2AX phosphorylation, and male meiotic sex chromosome inactivation. Curr Biol 14:2135-2142.

Xue F, Tian XC, Du F, Kubota C, Taneja M, Dinnyes A, Dai Y, Levine H, Pereira LV, Yang X. 2002. Aberrant patterns of X chromosome inactivation in bovine clones. Nat Genet 31:216-220.

Yeivin A, Razin A. 1993. Gene methylation patterns and expression. EXS 64:523-568.

Young LE, Fernandes K, Mcevoy TG, Butterwith SC, Gutierrez CG, Carolan C, Broadbent PJ, Robinson JJ, Wilmut I, Sinclair KD. 2001. Epigenetic change in IGF2R is associated with fetal overgrowth after sheep embryo culture. Nat Genet 27:153154.

Yu YW, Tsai SJ, Hong CJ, Chen TJ, Chen MC, Yang CW. 2005. Association study of a monoamine oxidase a gene promoter polymorphism with major depressive disorder and antidepressant response. Neuropsychopharmacology 30:1719-1723. 